\title{
Shift-learning: Suburban Teachers' Perspectives Towards Readiness and Media Learning Application During Pandemic Period
}

\author{
Fatimah Setiani ${ }^{1}$, Muhammad Sandy Al Fath ${ }^{2 *}$, Nikmah Sistia Eka Putri ${ }^{2}$, Rahmah \\ Dwi Sistiarini ${ }^{3}$, Ajah Saputra ${ }^{1}$, Herlina Hidayati ${ }^{1}$, M. Fatchurahman ${ }^{4}$ \\ ${ }^{I}$ Guidance and Counselling Department, STKIP Muhammadiyah Sampit, Sampit, Kalimantan Tengah 74312, Indonesia \\ ${ }^{2}$ Magister of English Education Graduate Program, Ahmad Dahlan University, , Yogyakarta 55161, Indonesia \\ ${ }^{3}$ State University of Malang, Malang 65145, Indonesia \\ ${ }^{4}$ Guidance and Counselling Department, Muhammadiyah University of Palangkaraya, Kalimantan Tengah 73111, \\ Indonesia
}

*Corresponding author. Email: msandyalfath@gmail.com

\begin{abstract}
In state-of-the-art era, technology leads people to changes of life. In the education context, especially in the pandemic situation, there is a transmission of learning way, from conventional to online which is called as Shift-learning. Not excuse, the remote area was affected too. Consequently, this study needs to be created as the evidence if the writers tend to contribute in this case. This study is designed as the case study. It conducted in the suburb area in Kotawaringin Barat, Central Borneo. The participants consisted of 5 English teachers who teach in different context (school and course). This study focused on the teachers' readiness and the media learning application in the pandemic era. The study revealed that teachers experienced forced shift learning. It can be said they are not ready in the preparation but they did great jobs in surviving to adapt in pandemic situation. Furthermore, WhatsApp was being a preference for suburban teachers in the instructional process. consequently, writers suggest that suburban teachers to improve their knowledge of current technology in education periodically by training to prepare the teacher adjusting the material that is suitable or contextual in accordance with the level of understanding of the students.
\end{abstract}

Keywords: Shift-learning, suburban teachers' readiness, media learning application, Covid-19

\section{INTRODUCTION}

Developmental of technology brings a bunch of change in every aspect to the world. It offers simplicity in every situation. Not excuse, in the education fields, it brings new concept; the sense of easiness in learning and teaching process, such as easiness of receiving information (knowledge) through the internet, conducting teaching and learning process in distance area. This new concept is called shift - learning, meaning that there are changes in educations fields especially paradigm; how they learn to produce the outcome, places; from classroom to platforms which do not need face to face, and sources; not only coming from Hardcover of book but also can be sourced from e-book, journal, and internet sources. [1]

As a way of technology in information and communication develops rapidly, the necessity for an IT-based concept and learning mechanism are going to be unavoidable. The concept that become discovered as e-learning, has brought the effect of the process of transformation of conventional or traditional way of education into digital or sophisticated form, both in contents and system. Currently, the concept of e-learning has been spready pass for the world people, as evidenced by the rampant implementation of e-learning, especially educational institutions. [2] Some universities organize electronic learning activities as a supplement to subject matter that is presented regularly in class. However, several other universities hold e-learning as an alternative for students who for one reason or another are unable to attend lectures face to face. In this connection, elearning functions as an optional choice for students.

The concept that became recognizably as e-learning carried the impact of the process in the transform of conventional education into digital form, both in contents and the system. In this concept, there is a combination of face-to-face meetings with electronic learning that can increase contributions and interactivity between students. [3] Through face to face, learners can get to know fellow students and their accompanying teachers. This familiarity is very supportive of their collaborative work virtually, besides that careful preparation before implementing multimedia-based learning also plays an important role in the smooth learning process. These two things become 
important factors in the learning process which we later refer to as e-learning.

In recent time, the world has been faced the pandemic named Corona Virus Disease 2019 (Covid-19) that bring the complex situations to all aspects of human life. Many aspects in this world have changed since this disease raised and spread to whole world. This situation forces human cannot be interacted physically in order impede the spreading of the disease. Many countries have gained this situation as strong as that they can. The role of technology helps human, especially medical people, to campaign this problem widely in order the holistic movement or corporation is created.

Interestingly, not only the medical field that are helped with the technology but also the education field. Technology has changed the pattern of teacher-student communication in the learning process. Massively, in this notorious period, the use of technology through the Media Application increased significantly to replace the face to face learning processes. However, previous situation leads Media Application was only the supporting system that cannot replace it. In fact, many formal schools are supported with the media learning platform such us zoom, Google classroom, etc.

For teachers, it should be mind - mumbling situations, especially teacher in the rural area in which the technology is not familiar to the teacher and students. However, the rapid development of technology has spread widely, they still do not know much about online learning even they never use it. It is because the decentralization that happen between big city and rural area. This article has raised up because of the phenomenon has been seen directly by the writers. Some teachers have the ability and others do not. It is actually a problem that must be tackled by all education components.

The significance of the study is about to give the information of readiness of the teachers who come from the suburb area when facing this unnormal situation or pandemic period. Furthermore, the detail explanation about the process of running the class is also presented as the contribution of this study. Those topics are aroused from the investigation of the researchers that conclude an assumption that the suburban teachers are in trouble in the process of adaptation to online learning system that might be unfamiliar for them which are impacted from decentralization [4].

Moreover, this study is keenly interested to explore How are suburban teachers' perspectives towards readiness and experiences in operate media learning application in instructional process during pandemic situation? Consequently, this study can also be the cornerstone of taking into account what has been undergone in the current decentralization. Is the current decentralization going to be worst or contrariwise? this study takes a vital place in the teacher perspective to plan and apply the best way of teaching for them and knowing how big the improvement of the country to gain the complicated problem. The main point of this study is about vital data due to the urgency which is needed for the education policy holder in taking a national dictum.

\section{LITERATURE REVIEW}

\subsection{Learning Transmission culture (Shift- learning)}

In state-of-the-art era, technology leads people to changes of life. Sophisticated tools raise up by the expert through their innovation idea and product. In the education context, some changes underwent rapidly and innovatively. According to Al Fath, Aziz, and Murwantono [5] said that the transformation of learning way, from conventional to online, is called as Shift-learning.

\subsection{Online Learning}

E-learning or Online Learning systems are different from learning that is usually held in class (traditional learning). The key to the effectiveness of an e-learning program's success is its students [6]. Students, in this case, are required to be more active because the main process is with students as learners [7]. This is consistent with the view of constructivism to see the learning process as an active process that is obtained through his own experience. In the context of e-learning learning students are "forced" to be actively involved in the learning process and students have greater flexibility in choosing learning materials to be learned, where and how they will learn, which in turn will accelerate access students' statements as the centre of their own learning experience. In this condition students' willingness and readiness to learn especially those related to self-study need to be a major consideration.

The Logic acceptance of e-learning that provides an interpretation understanding that e-learning in education are: 1) e-learning as distance learning which defines elearning to allows students educational activities without any physical interaction directly with the instructor. However, educators will conduct learning interaction activities online in the form of real-time off-line and archival access. 2) e-learning as Learning with the help of computer equipment which means that e-learning is carried out using or utilizing computer media that is equipped with multimedia devices, Internet connections or local Intranets. 3) e-learning as formal or informal learning which means that e-learning in learning can be done formally or informally for example by learning to still have the same curriculum, syllabus, subjects and tests with non-e-learning learning but utilizing online facilities [8]. While for informal learning through simpler interactions, such as means of mailing lists, e-newsletters or websites.

Hirsh [9] elaborated in detail about E-learning infrastructure devices as follows: 1) e-learning Systems and Applications Educational science: e-learning software systems are systems that virtualize conventional teaching and learning processes. This virtualization such as How is classroom management, material or content creation, discussion forums, group discussions, grading systems, on- 
line examination systems and some features related to learning management such as depositing assignments and accessing the information on assignments received including grades earned. 2) Educational e-learning Content: Content and teaching material available in elearning Educational science is a system that provides a management system that contains content and teaching materials in the form of multimedia-based content (interactive multimedia content) or text-based content (content in the form of text as in ordinary textbooks), which is stored in web archives

The context of education in higher education, learning objectives are more directed at how to develop students' ability to want to continue learning (continuous learning) and also stimulate high order thinking. The use of technology provides opportunities for educational institutions to be able to stimulate both goals, one of which is by combining face-to-face learning with technology (elearning) or blended learning. Duncan, Miller, and Jiang revealed that the main key is how they facilitate the process of excavation through the community or community of inquiry [10]. Community of enquiry itself is one of the online learning models states that educational experiences occur when collaboration occurs between individuals and their social environment, through the inquiry process. The inquiry process itself requires three elements to provide an educational experience to individuals in the context of online learning, namely cognitive presence, social presence and teaching presence [10]

According to Irawati, Yovita, \& Iqbal [11], given the importance of the presence of these three factors in the process of student learning, they revealed the need for students' readiness to participate in learning by using computer media (e-learning). Telkom University (d.h. Telkom Institute of Technology) itself since 2009 has been developing and implementing e-learning [12]. At the beginning of implementation, e-learning was implemented to complement existing traditional learning systems, but in 2015 , it is not only be completed but will become one of the leading methods in teaching and learning (PBM). The results of interviews with lecturers who have used elearning, generally students are not familiar with the active learning process. Students still rely heavily on lecturers to explain the material face to face. Not many lecturers have opened discussion forums using online, but generally, lecturers invite their students to ask questions online. It is a pity that students rarely use this facility, even though elearning actually has a strong potential for students and colleagues or lecturers to conduct reflective thinking processes with their ability to record the results of discussions. So far, it does not measure the readiness of students for the e-learning learning process yet. The results of a survey conducted at Telkom University engineering students showed attitudes and study habits that still relied on lecturers to be the main facilitator, and observations that had been made showed that student participation in the course was still low, especially those conducted through online. One problem is the lack of inconvenience of students to hold discussions or express their opinions or ask questions in a forum.

As the ages grow, many aspects were distorted. Education field also had been getting the impact of this development. Furthermore, students belonging take place in shaping behaviour and the learning process. The changes in the learning process (paradigm, place, and resources) must be described clearly to inform the information widely to the teacher in order to adapt to student's necessity. The description of the problems can be considered for teacher treated students in the classroom. It leads to the quality of teaching and learning process, especially to suburban students. They need to be treated properly in order to maximize the process of knowledge input in the best way.

\subsection{Media Learning Application}

Learning media can be revealed as variety of components in the learning environment in order to help students learning process. The use of appropriate learning media can help improve student learning abilities. He argues that someone will learn better when studying text from projectors and laptops or preparing drawing media rather than text media only.

Most students from rural areas have barriers to enriching English communication skills. Conventional teaching methods that create boredom for students are expected to have new teaching methods and techniques. the use of computers in the world of communication technology has succeeded in gaining a fundamental role in the education process. Computers are becoming more attractive to teachers and students because of their enormous abilities and broad effectiveness. The use of instructional media in teaching is an innovative method introduced in many tertiary education institutions [13].

The limitations of learning media that can help students boosting their skills in writing and fostering students' interest are also obstacles faced by teachers. Therefore, various works are required from the English teacher to encourage students' abilities in reaching predetermined writing learning goals [14]

During the COVID19 pandemic, the role of social media such as WhatsApp, e-mail, Google drives, zoom applications, Google classrooms has become a major source of education throughout the world. In crises such as this social media COVID-19 has been mastered and used to be used responsibly by educational institutions.

\subsection{Media Learning Application}

In March 2020, schools in Indonesia began to prepare for the possibility of a corona virus epidemic that would strike the community. Lot plans made for teaching must be online. The teaching and learning process were forced to stop face-to-face meetings because of government instructions to reduce the spread of the virus due to faceto-face. In April 2020, teachers were instructed to report 
on work to teach with distance instruction because schools were closed to students.

Since mostly schools were closed due to the COVID-19, the school had to stop face to face teaching and learning process in class into online system education because of concerns it would occur [15]. Schools that apply sophisticated tools to raised online education up can restrain students from being left behind academically. However, the process of online system might be implemented poorly [16]. This situation can be difficult implementing online education to prevent students from lagging behind. To adapt with the condition, numbers of institutions have transformed their services for learners in assisting to the pandemic period [17].

In response to the pandemic, the school created school virtual learning plans that have assisted educators to update online teaching on effectiveness of practices used by schools in the of world disease period [15]. The internet can be one of the preferences for teachers to look after other free online resources that can produce learning opportunities. Teachers also need to check students regularly, especially those who are less skilled with digital tools [18]. The schools that cannot implement online education properly during school closure may have to think about keeping their students from lagging behind. Schools that choose to apply online learning are likely to face challenges. As schools and teachers gain experience with online education during this difficult time, they will likely learn valuable teaching management methods and strategies in the future [19].

\section{RESEARCH METHOD}

This study is a case study that covered the teachers Perspective on the change's way of learning in the pandemic situation. The purpose has explained by Pacho [20] that it is to understand the situation of a particular individual, programme, or event being studied for a time period definition. Further, this study utilises purposive sampling technique to choose the participant of the study [21]. It involved four English teachers who taught English at different school or course in Kotawaringin Barat. However, it is not required as the 'ideal' number of participants for a case study as explained by Leedy \& Ormrod [22] that the ideal number of participants is at least 6 until 8 . This happened because of the time limitation and obstacle faced by the researcher in finding the participants that still run their process of teaching and learning in the pandemic situation at a village or isolated area. Since the dictum of government that suggest people to undergo physical distancing leading to cut the disease spreading.

Nevertheless, the study remains to give rich descriptive information toward the perspectives and implementation of shift-learning are faced by teachers. Thus, the researcher used interview, observation and documentation as instruments in data collection. Interview was conducted on teachers' perceptions to know how ready the teachers to teach through online learning in the pandemic situation and to know how the instructional process have undergone in pandemic situation. Moreover, the data interview will be taken via WhatsApp chat and WhatsApp Video Call to keep safe and in line to government rule.

Then, documentation will be used to ensure another instrument, such as collecting the data from any references and attempting to manufacture the triangle of the data. After that, the data transcription of interview and documentation were being coded into some categories. Then the categorized data were analysed and described argumentatively.

The steps of analysing the data in this study as follows: (a) selecting the specific answers how the students deal with e-learning; (b) classifying the specific answers based on the challenges that occur; (c) classifying the answers of core Knowledge about E-learning into a table and (d) drawing the conclusion and verifying the data by considering the result of data analysis.

\section{FINDINGS}

\subsection{Finding of Observation}

In this level, the teachers were selected by the researcher through the enjoy conversation with the teachers and students in Kotawaringin Barat concurrently in order to get the preface of the information. Furthermore, there are 3 kinds of English teachers (School English Teachers, Institution course English Teachers, and Independents private English Teacher). There is a fact that they all have been finished the teaching activity such as the school teachers who has in the end of semester, Institution Course English teachers got holiday during the pandemic after trying online teaching way, and the independents private English teachers experienced only 2 weeks when pandemic has come.

Another problem is about the unstable internet connection, it caused educators cannot be applying the application or platform that needs stable connection such as zoom etc.

Moreover, the problem above depicts that they are suffering due to the unsupported system (internet connection) and the learning culture (transformation from conventional to online) in the pandemic situation. This problem shows that knowing the implementation of shift learning and the instructional processes are vital because for some cases this situation can stop the teaching and learning processes.

In the other hand, researcher also surveyed about the range of ages of English teachers which classified as the young generation. They consist 22, 23,24, 26, 37 years old means that that English teachers in the suburb nowadays are the young generation. 


\subsection{Findings of Data Interview}

\subsubsection{Suburban Teachers' Readiness to the Changes Learning Way in Pandemic Situation}

Overall, teachers' readiness cannot be said a hundred percent ready. Despite minor conclusion, all of teachers depict some positive and negative information to adapt with the new system of teaching and learning. Here is some information that were showed up from teachers' perspective especially in some aspects of teachers' readiness such as the strategy, technique, structure, skills, style, and value in process of instructional education.

\subsubsection{Strategy: goals and strategy}

For this case, teachers A said that this is the hardest part that need to be paid attention. The findings found fact that objective of learning goal of the instructional process in the pandemic situation for suburban teacher are not changed at all. However, the teachers said that the cognitive aspect is more raised up even experiencing the pandemic situation. It is because that they depict the assessment still come from the students' assignments. It shows from the answer of teachers in the interview section, which said:

"The aim of study is not changed like the planning, I still do teaching and learning and also assessing as usual. So that I take students score from their assignment" (Teacher A)

It also can be said that RPP (Lesson Plan) is not changed much because of the pandemic. The teachers just remake lesson plan in the way how the materials delivered. Moreover, in the strategy of learning, teachers argued that to support the goal of learning the materials and how materials delivered are in vital position. teachers said that miscommunication might be experienced if the material are not clear and interesting to explore. Beside it, culture affected it as the topic that need to be paid attention. Teachers and students in the suburb are different in culture of process because before the pandemic, the process of learning never does the online learning system. The interview excerpt is presented below:

"For me, the materials and the way of transferring the material is very important because of the miscommunication can be happened during the teaching and learning process. Yeah, you know, we never do the thing like this before (online learning system)". (Teacher B)

\subsubsection{Systems Technical}

In the state-of-the-art era, civil facilitation become important to support the sophisticated system such online system that need the stable connection. In the suburb, they still cannot get the stable connection due to the decentralization affecting to the facility of that area. Even that condition real, government does great job in the current situation. Connection can be stable in the communication application such as WhatsApp, Telegram and others. However, the application such as zoom, Google meet others still can be used effectively due to the internet connection.

Strikingly, besides the internet connection, not all suburban students get the mobile phone or laptop from their parent especially in junior high school level. This is also become problem in the instructional process in the suburb area. Like what were said by the teachers:

"The internet connection sometimes good but sometimes bad even can be said very bad". (Teacher C)

"I take a view that about the technical system got trouble in tool. Why? it is because the not all students have the mobile phone or laptop to follow the online system, they are lent by their parent to joining the online class, but sometimes they got trouble because of the parent also use it”. (Teacher D)

\subsubsection{Structure}

In the structure of learning, there are two centralization perspectives in this case. Firstly, school centralization. Actually, there are no centralization that is provided by school, the teachers only manage online platform to support the instructional process. The school gives freedom for teacher to use what platform is matched with the class environment. However, Teacher A said that headmaster gave assumption to specific online learning, but the school does not provide platform anymore.

Secondly, Teachers take the initiatives to decide what platform that is used in the process of learning in pandemic. All teachers said that WhatsApp is the best choice media in the condition of the suburb due to the stability of the internet connection. Moreover, they argued WhatsApp more familiar for students in the suburb because it is the daily application used for the students, then, it led the process of learning are more effective than the new one.

\subsubsection{Style/culture: Shift Learning}

Teachers confidently said that the students are not ready yet for experiencing this situation. It because the students have no culture on it or never use online learning system before. Furthermore, teachers also said that the old teachers' generation, up to 40 years old, got trouble in adaptation especially for adapting to sophisticated tools. In the other side, young teachers experienced smooth adaptation because they are familiar to technology. 


\subsubsection{Skills: training}

Actually, all participant never got any training before. However, one of the teachers told something 2 days after the interview had done, she said that they got training for using Google form to face the examination, but she said the teachers (especially the old teachers) in that school were wasting the time for only learn how to make email account. So, the training become not effective which led the confusion after training. She said the condition after training, the old teachers ask help for the young teachers to teach them the step one by one. Something that must be thanks to god is the teachers do not give up for the notorious situation.

\subsubsection{Share/value: share belief}

Teachers said, overall, they are ready to face the shift learning to the new system. However, some old teachers need to be paid attention to ensure the affectivity of online classroom activity. It is actually is normal condition, because not all teachers are tetchy. So, they need the time to adapt effectively to the situation.

Moreover, the conventional way of teaching and learning process is still become favourite of teachers even they have been undergone the online learning system. All of participants said that face to face method cannot be replaced to keep the communication run properly.

\subsubsection{The Teachers Experience in Operate Media Learning Application in Instructional Process}

The implementation of social distancing to prevent the spread of COVID-19 in the pandemic period has encouraged teachers and students to utilize media learning applications to be able to carry out online teaching and learning processes that take place in the home. The pandemic situation has been altered some system of educational process. Habit activity changes differently. Here are the data that shows clearly the experience of instructional process in the isolated area.

According to teacher interview data, the teacher recommend WhatsApp is appropriate media learning application in suburb area during pandemic situation. This assumption is borne out in the extracts from the lecturers' interview shown below:

"WhatsApp application is recommended for remote learning in other subject in future especially in this pandemic period." (Teacher B)

\subsubsection{Pre-activity (planning)}

Teachers continue the lesson plan that have been made before. However, teachers must be adapting the activity to online learning system (shift-learning) and innovate the material to be more interesting. It is beneficial for the affectivity in the online class which means those activity aims is to lead students to be more understandable to the given materials.

"I need more time in improving appropriate on-line materials that mostly took a lot of time rather than learning in classroom." (Teacher A)

"I need to change several learning activities for classroom into online activity". (Teacher B)

"I asked students to do online activity to browsing material which relevant with the topic will being to discuss". (Teacher C)

\subsubsection{Core-activity (the process)}

The instructional process in the suburb looks simply. The teachers do not use the common application in the pandemic such as zoom, Google meet, Google classroom etc. the chosen media of suburban teachers is WhatsApp application which usually has been used to be the communication application. It is concluded because all of participant prefer to this application for their classes especially along the pandemic situation.

The teachers depict that WhatsApp might be covered some strategy of teaching and learning process. Along the interview, there are 3 way of teaching and learning that applied by teachers through WhatsApp, they are Video Recorder, Video Call, and Group Discussion. The interview excerpt is presented below:

"We use Video Recorder, Video Call, and Group Discussion in group discussion we discuss topics or respond to the opinions of friends or answer questions from us." (Teacher A)

"The online learning process uses the WA application by delivering material for students". (Teacher B)

"Learning is carried out online but the collection of tasks still uses WhatsApp Group". (Teacher C)

"I use WhatsApp as a place to give instructions to students in the form of material to be studied, and assignments. Especially every week students are asked to actively discuss in WhatsApp Group". (Teacher D)

"Students can record their voice in video call or voice note recorder in speaking activity or oral test performance". (Teacher E)

However, the contrary fact happened in the teachers' obstacles in the instructional process which looks so complicated. Communication between teachers and students in the process of teaching and learning is not run effectively. All participants said that they are doubt to students' material understanding. Teachers argued that they got trouble in measuring how far the students received the information given. The evidence of the challenges of WhatsApp as expressed in the following comments by teachers:

"The challenge is finding material that is relevant to the topic of the material, because the students' digital literacy sometimes too broad and out of topic". (Teacher A)

Strikingly, another notorious fact raised up in the interview section. One of teachers said that, she was little bit 
confused about the current condition. She said that it happens due to the obstacle in measuring students and obligation as the teacher to reach the aim of study in the syllabus. The teacher merely thinks about the quantity of material delivery without thinking about quality of material received. It shows this teacher has been frustrated which leads the teacher try to do not care about the problem.

Moreover, unsupported systems notoriously contribute to complicated problem that is faced by teachers. It consists culture and facility. In this case culture of learning of suburban students stand differently to the students in the big city. They do not familiar with sophisticated tools in the instructional process. It leads the students allocate time and effort to adapt with the new system of learning. Still in the cultural obstacles, as we know, in this situation the awareness of self-learning form students is need maximally. The students are forced to fill in the necessity of their literacy meaning that the cultural literacy will bring a lot of differences. In the other side, facility also holds the essential position. The most valuable function in this situation is to support the new system effectively. However, in the suburb area, the decentralization effects are daily undergone such as unstable internet connection, teachers' skills and sophisticated devices.

\subsubsection{Close Activity (closing)}

This, closing, is the last activity on instructional process. It relates to assessment activity to students' results. Measuring the students' results is not as easy as seen. Especially in 2013 curriculum there are 3 aspects (affective, cognitive, and psychometric) that have been measured. However, in the implementation of instructional process, especially in pandemic situation in the suburb area, students are measured mostly only form the cognitive aspect due to the limitation of meeting and communicating in the class. Furthermore, despite the measurement aspect, there are another unideal measurement way to assess the three measurements concerns with the existing dictum. It is about the assessment that merely aim to individual score in examination. The interview excerpt is presented below:

"Online learning looks more at the cognitive aspects of students in taking exams." (Teacher A)

"Affective aspect and psychometric aspect of students is rather difficult to see when learning online". (Teacher B)

"I think the evaluation and evaluation of online learning is rather difficult because I am not accustomed to it yet". (Teacher $C$ )

Most of them operate the same application with the instructional process, non-formal and formal condition, which is still prefer to WhatsApp like the instructional process underwent. The process looks so simply. Teacher sent question in the class-group and students answers sent to teacher personally. The process of giving and answering question from teachers and students managed in writing respectively. They did not utilize computer or laptop, they only use hand writing to do both activities. Teachers also revealed that students score is stable. There are no up and downs data that happen in the final score. The score is gotten as capable as students' abilities.

Furthermore, there are another teacher managed Google form as the platform to examine the students. Strikingly, in the formal education one of teachers got training for using the Google Form. However, the training was not managed effectively due to the participants skills that are not tetchy. Not all teachers can be said skill able to use internet, most of participants are the old generation which basically using internet not for learning and teaching process. The teachers said:

"The training is easy to do, the biggest problem is the practical classes". (Teacher A)

"I think the training help us but it is consumed for 2 hours for old generation in managed or just for creating email account." (Teacher B)

"The teachers who lack of internet skill faced problem to do instructional process". (Teacher C)

\section{DISCUSSION}

\subsection{Teacher Underwent Forced Shift Learning}

In this part, the topics discuss about teachers' readiness and practice of instructional in the pandemic situation. Teachers perspectives were being the data in this study. From the data above, there has been raised up some information such as forced shift-learning and Media learning application used in the pandemic situation.

This perspective, forced shift learning, is taken from the teachers experience in undergoing the instructional process of suburban. (see figured 1)
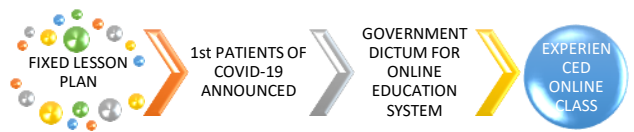

Figure 1 The process of why forced shift-learning happened in suburban teachers.

From the data in the finding, it can be concluded that the chart depicts the occurrence of what was happened in the pandemic situation. Before the pandemic spread, the teachers had prepared a lesson plan and had run in the conventional system. It has been shown that suburban teachers were done their obligation to face the semester [23]. However, the disease notoriously affected teachers and students to undergo forced shift-learning. Lucky, the lesson plan was not altered a lot since the forced shiftlearning happened. They merely adapt the way of delivering information (Material Study) differently than before.

When the 1st case of this diseases come up, the government took steps to hold back the spreading of the virus. The way that was given by government to people was aimed to decrease mobility of people. This dictum affected all aspects in the country. Not excuse, education field, it altered the way of teaching and learning process from the conventional to online system. This impact 
transmits widely including to the area where people still do not know much about technology like in the suburb. In fact, the teachers in the suburb almost never teach sophisticatedly due to their unsupported condition such us devices, teachers' skills, students' readiness and internet connection like what has been written in the finding section.

Actually, forced-shift learning happened because of unpredictable accident in the process of teaching and learning which was run. Moreover, it was strengthened by government's dictum that was taken accidently. It led the education system are not ready 100 percent to face the changes. Then, government said that this accident can be tackled by the online learning platform.

Notoriously, for the suburban teachers, it is being the new problems especially in readiness aspects. The new system needs media to be the bridge to experience instructional process but still obeying the government instruction [23]. In fact, this is the cause of some problems starting to be raised in suburban teachers' life. The teachers' readiness can be seen thorough indicators of readiness based on Kariyev et al [24] stated that there are 3 indicators of teachers' readiness such as motivational, content-based, and procedural.

The motivational component belongs to teacher's professional orientation and the professional vision to ensure the quality of the object, in this case is to students understanding in the new system. in order to ensuring the quality of the students, teachers are required to be creative. Contradictory, the findings showed the teachers got frustrated with the system. Two of teachers argued that they just giving some materials without knowing the result of receiving quantity and quality of delivered information. It is something that must be paid for to teachers in the suburb area.

Furthermore, content-based, it is described by teacher's knowledge on the object which means teachers cognitive aspect on the system that happened in shift-learning process. It is proof by teachers' arguments that said they are merely got training from the school or institution which is shaded the school. Moreover, Tshabalala et al [25] presented that limited knowledge and skills to use technology as an obstacle to effectiveness among instructors language students by following the training teachers can open the inspiration in teaching and learning. Then, procedural component is the last indicator of teachers' readiness which reflects to teachers' skills on operating the system. Actually, here, the effect of what is teachers' generation took a place. The culture of generation gave different adaptation way. For us, this also impact to teacher's performance in online system. It is depicted from the teachers convey the story when the school provided training for undergoing the final examination by online but it was failed for the old generation. Actually, it makes sense due to the old generation was on up to 40 years which included in the range of $\mathrm{X}$ boomers and Millennials generation. Most of them do not familiar with technology. However, the millennials generation, nowadays, is familiar with the good adaptation in technology, in fact, most of suburban teacher included that generation still confuse in operating application. Positively, they are better than their previous generation which in their life culture, technology is not very familiar.

Strikingly, English teachers in suburban are dominated with the next generation after Millennials. They are called Generation Z. Based on Fath [26] this generation is quite different from the previous generation. Their cultural activities are very fit into technology. They experience the process of adaptation in this pandemic easier than other generation. It is because one of their characteristic's generation is tetchy which led them easy to adapt with technology.

Overall, the teachers' readiness is underneath the criteria of good readiness because of it was the accidently occurrence, but they did great job in adapting process especially in English young teachers. However, other teachers, old generation, need to get appreciation due to their effort to adapt with the system.

\subsection{WhatsApp was Being Preference for Suburban Teachers' in Instructional Process}

Spread of corona virus (COVID-19) has affected all elements global citizens, including Indonesian and academic people community in it. The teachers do not use the common application in the pandemic such as zoom, Google meet, Google classroom etc. Students are not familiar with the features of the learning management system (LMS), so this is quite an obstacle in the implementation of online learning. To address this problem, some lecturers only end up using the WhatsApp social network so that learning continues [27]. According to Lyashenko [28], LMS is aimed Improving digital skills of teachers and students, Creating conditions for active interaction between students and teachers.

The chosen media of suburban teachers is WhatsApp application which usually has been used to be the communication application. The teachers prefer to this application for their classes especially along the pandemic situation. The teachers depict that WhatsApp might be covered some strategy of teaching and learning process they are Video Recorder, Video Call, and Group Discussion. Furthermore, the easiness of using WhatsApp belongs to their congenital generation in this sophisticated tool era. In other words, they are included as the digital natives or Gen $\mathrm{Z}$ students having an interesting sense to the product of technology [26].

WhatsApp is the best choice media in the condition of the suburb due to the stability of the internet connection. Moreover, they argued WhatsApp more familiar for students in the suburb because it is the daily application used for the students, then, it led the process of learning are more effective than the new one. The teacher has been used WhatsApp as application reference in educational process from lesson plan planning, core activity in online learning, and close activity. Using WhatsApp that is easy 
to operate is widely used by teachers in suburban areas. WhatsApp is used from the beginning to the end of the semester exam during a pandemic period because there is an offline meeting in the classroom.

The use of WhatsApp application because both teachers and students have the application in their respective Smartphone. The WhatsApp application is equipped with a multi chat or WhatsApp group (WAG) feature, so that teachers and students can join in one discussion group to discuss lectures. In addition, this application also allows all members to share files by sharing types. This is used by teachers to share learning materials and assignments. Then students gather their assignments back into the WhatsApp group.

The pandemic situation has been used WhatsApp as application reference in educational process start from lesson plan planning, core activity in online learning, and close activity as final stage. Using WhatsApp that is easy to operate is widely used by teachers in suburban areas. WhatsApp is used from the beginning to the end of the semester exam during a pandemic period because there is an offline meeting in the classroom. This finding shows the key role of human touch as a conventional method in a face-to-face learning environment as opposed to an online learning environment. Similarly, Ahmad \& Al-Khanjari [29] suggest that e-learning is very useful, but it cannot replace face-to-face learning, entirely.

In pre-activity or planning stage, the teacher prepares lesson plan and learning material for the students. In line with Cheung [30], the teacher experienced a very heavy workload due to the preparation of materials for this course. In core activity or process in operate this online media application. Especially in English learning activities, students who learn by utilizing voice messages on WhatsApp are significantly superior to verbal communication skills than those only through text messaging on WhatsApp. Therefore, utilizing active voice messages in the WhatsApp Chat Group (WCG) can be recommended as an efficient technique for improving learning English as a Foreign Language [31]. While, in close activity for assessment in pandemic situation in the suburb area, students are measured mostly only form the cognitive aspect due to the limitation of meeting and communicating in the online class. In line with Mukhtar, et.al [32], states teachers and students viewed inefficiency to teach psychomotor skills, resource intensiveness and mismanaged decorum during sessions as limitations of online learning. The learning process in pandemic situation is used online learning as alternative instructional process which there is no offline learning in the class. Furthermore, the COVID-19 pandemic highlights the need to use online models and applications to achieve the learning goals [33] [34]

\section{CONCLUSION}

The suburban teachers' readiness is underneath the criteria of good readiness because of it was the accidently occurrence, but they did great job in adapting process especially in English young teachers during pandemic situation. However, other teachers, old generation, need to get appreciation due to their effort to adapt with the system. Teacher experiences in operate WhatsApp media learning application in instructional process during pandemic situation which usually has been used to be the daily communication application before. The teachers prefer to this application for their classes especially along the pandemic situation. The teachers depict that WhatsApp might be covered some strategy of teaching and learning process they are Video Recorder, Video Call, and Group Discussion.

\section{REFERENCES}

[1] Abdulazeez and Zeebaree, "Design and Implementation of Electronic Learning System for Duhok Polytechnic University," Academic Journal of Nawroz University, vol. 7(3), pp. 249-258, 2018.

[2] A. G. J and G. P. G, “Open and Distance eLearning: New Dimensions in Teaching, Learning, Research, and Extension for Higher Education Institutions," International Journal on Open and Distance Learning, vol. 1 (December), p. 1-13., 2015.

[3] L. Chen and L. Tao, "Teaching Web Security Using Portable Virtual Labs," in 2011 IEEE 11th International Conference on Advanced Learning Technologies, Athens, 2011.

[4] Wepner, S B; et all, Changing Suburbs, Changing Students: Helping School Leaders Face the Challenges, California: Corwin: A Sage Company, 2012.

[5] M. S. Al Fath, M. A. Azis and D. Murwantono, "Shift-learning towards remote area on freshers of english education at Universitas Ahmad Dahlan," KEMBARA Journal of Scientific Language Literature and Teaching, vol. 6(1), pp. 93-103, 2020.

[6] P. A. J. Hsieh and V. Cho, "Comparing e-Learning tools' success: The case of instructor-student interactive vs. self-paced tools," Computers and Education, vol. 57(3), p. 2025-2038, 2011.

[7] E. Kassens-Noor, "Twitter as a teaching practice to enhance active and informal learning in higher education: The case of sustainable tweets.," Active Learning in Higher Education, vol. 13(1), p. 9-21. , 2012.

[8] J. L. Moore, C. Dickson-Deane and K. \& Galyen, "E-Learning, online learning, and distance learning environments: Are they the same?," Internet and 
Higher Education, vol. 14(2), p. 129-135, 2011.

[9] S. Hirsh, "A new definition," Journal of Staff Development, vol. 30(4), pp. 10-14, 2009.

[10] I. Duncan, A. Miller and S. Jiang, "A taxonomy of virtual worlds usage in education.," British Journal of Educational Technology, vol. 43(6), p. 949-964, 2012.

[11] D. Irawati, V. Yovita, Leanna and M. Iqbal, "Peranan aplikasi simulasi jaringan komputer dengan sistem e - learning pada studi kasus di universitas telkom.," Prosiding SAINTIKS FTIK UNIKOM, vol. 1(1), p. 37-41., 2015.

[12] Indrayani, D., "Peranan Aplikasi Simulasi Jaringan Komputer Dengan Sistem e-Learning Pada Studi Kasus di Universitas Telkom.," Prosiding SAINTIKS FTIK UNIKOM, vol. 1(1), pp. I.37-I.44, 2015.

[13] E. Arulselvi, "Effect of Instructional Media in the Learning of English Grammar on the Achievement of Teacher Training Students at Namakkal District," Journal on English Language Teaching, vol. 3(1), p. 80-87, 2011.

[14] Aryuntini, N; Astuti, I; Yuliana, Y, “Development of Learning Media Based on VideoScribe to Improve Writing Skill for Descriptive Text of English Language Study," Journal of Education, Teaching and Learning, vol. 3(2), p. 187-194., 2018.

[15] S. Noonoo, "Students are lonely:' What happens when coronavirus forces schools online. EdSurge.," EdSurge, Portland, 2020.

[16] H. Morgan, "Online instruction and virtual schools for middle and high school students: Twenty-firstcentury fads or progressive teaching methods for today's pupils?," The Clearing House, vol. 8(2), p. 672,2015 .

[17] E. Tate, "With weeks of e-learning ahead, be flexible and forget perfection. EdSurge.," 3 March 2020. [Online]. Available: https://www.edsurge.com/ news/2020-03-19-with-weeks-of-e-learning-ahead-beflexible-and-forget perfection.. [Accessed 4 May 2020].

[18] J. Snelling and D. Fingal, "International Society for Technology in Education," 16 March 2020. [Online]. Available: https://www.iste.org/explore/10strategies-onli. [Accessed 4 May 2020].
[19] H. Morgan, "Best Practices for Implementing Remote Learning during a Pandemic.," The Clearing House: A Journal of Educational Strategies, Issues and Ideas, vol. 93(3), p. 134-140, 2020.

[20] T. Pacho, “Exploring Participants' Experiences Using Case Study," International Journal of Humanities and Social Science, vol. 5(4), p. 44-53, 2015.

[21] Etikan. I "Comparison of Convenience Sampling and Purposive Sampling," American Journal of Theoretical and Applied Statistics, vol. 5(1), no. https://doi.org/10.11648/j.ajtas.20160501.11, p. 1, 2016.

[22] P. D. Leedy and J. E. Ormrod, Practical research: planning and design, Prentice Hall: Upper Saddle River, N.J., 2005.

[23] S. Sesiorina, “The Analysis of Teachers'Lesson Plan in Implementing Theme-Based Instruction for Teaching English to Young Learners," Journal of English and education, vol. 2(1), pp. 84-95, 2014.

[24] Kariyev, A. D, Selkebayeva, A. T, Bespayeva, G. K; Baigundinova, B. I; Kabdualieva, A. G, "A study of teacher's readiness for teaching students by methods of interactive learning as a condition for developing students' creative abilities," Revista ESPACIOS, vol. $39(21)$, p. $15,2018$.

[25] Tshabalala, M; Ndeya-Ndereya, C; Van Der Merwe, T, "Implement blendedlearning at a developing university: Obstacles in the way," Electronic Journal of e-Learning, vol. 12 (1), pp. 101-110, 2014.

[26] M. S. Al Fath, 'Investigating Gen Z students' perceptions on the use of Instagram to improve vocabulary," IAIN Palangka Raya, Palangka Raya, 2018.

[27] G. Gunawan, N. M. Y. Suranti and F. Fathoroni, "Variations of Models and Learning Platforms for Prospective Teachers During the COVID-19 Pandemic Period," Indonesian Journal of Teacher Education, vol. 1(2), pp. 61-70., 2020.

[28] M. S. Lyashenkoa and I. A. Malinina, "System projects for teaching a foreign language in the university.," Procedia - Social and Behavioral Sciences, vol. 182, p. $81-88,2014$. 
[29] N. Ahmad and Z. Al-Khanjari, "Effect of Moodle on learning: An Oman perception," International Journal of Digital Information and Wireless Communications (IJDIWC), vol. 1(4), pp. 746-752, 2011.

[30] B. Cheung, B. Stewart and R. McGreal, "Going mobile with Moodle: First steps. Mobile Learning.," in IADIS International Conference Mobile Learning, Dublin, 2006.

[31] A. A. Minalla, "The Effect of WhatsappChat Group in Enhancing EFL Learners' Verbal Interaction outside Classroom Contexts," English Language Teaching, vol. 11(3), pp. 1-7, 2018.

[32] K. Mukhtar, K. Javed, M. Arooj and A. Sethi, "Advantages, Limitations and Recommendations for online learning during COVID-19 pandemic era," Pakistan Journal of Medical Sciences, vol. 36, 2020.

[33] S. L. Schneider and M. L. Council, "Distance learning in the era of COVID-19," Arch Dermatol Res, 2020.

[34] Verawardina, U; Asnur, L; Lubis, A. L; Hendriyani, Y; Ramadhani, D; Dewi, I. P; Darni, R; Betri, T. J.; Susanti, W; Sriwahyuni, T, "Reviewing online learning facing the Covid-19 outbreak.," Talent Development and Excellence, vol. 12(3s), p. 38, 2020. 